Buddayah: Jurnal Pendidikan Antropologi, Volume 1, Nomor 1, 2017, 19-26

\title{
KEHIDUPAN PETANI KEMENYAN DALAM MENJAGA KEARIFAN LOKAL DI DESA PANDUMAAN KECAMATAN POLLUNG KABUPATEN HUMBANG HASUNDUTAN
}

\author{
Lamria Simamora
}

Alumni Prodi. Pendidikan Antropologi Fakultas Ilmu Sosial Unimed

\section{Nurjannah}

Staf Pengajar di Prodi. Pendidikan Antropologi Fakultas Ilmu Sosial Universitas Negeri Medan nurjannahfis@unimed.ac.id

\begin{abstract}
Abstrak
Artikel ini mendeskripsikan mengenai "Kehidupan Petani Kemenyan dalam Menjaga Kearifan Lokal di Desa Pandumaan Kecamatan Pollung Kabupaten Humbang Hasundutan”. Skripsi ini menjelaskan tentang hal-hal yang melatarbelakangi kehidupan petani kemenyan dalam menjaga kearifan lokal. Melihat bagaimana gambaran perjuangan petani kemenyan agar tetap eksis dan bertahan bertani kemenyan walau kehadiran perusahaan industri merusak dan mengganggu kemenyan sebagai kearifan lokal. Kemudian penelitian ini menggunakan metode penelitian kualitatif dengan pendekatan deskriptif. Dalam hal ini yang menjadi informan adalah masyarakat desa Pandumaan yang bekerja sebagai petani kemenyan dan terlibat dalam mempertahankan kemenyan dari pihak industri maupun permerintahan. Sementara itu teknik pengumpulan data yang digunakan dalam penelitian ini yaitu observasi, wawancara, dan dokumentasi. Hasil penelitian menunjukkan bahwa hal yang melatarbelakangi petani kemenyan menjaga kearifan lokal di Desa Pandumaan Kecamatan Pandumaan adalah dikarenakan (1) Kemenyan merupakan sumber kehidupan yang mampu memenuhi kebutuhan hidup, (2) Merawat nilai-nilai kultural yang terkadung dalam pengelolaan kemenyan serta menjadi tanaman unggul yang menjadi kearifan lokal, (3) Kemenyan sebagai warisan budaya yang sudah dikelola sejak ratusan tahun, (4) Kemenyan merupakan tumbuhan endemik yang tidak dapat tumbuh disemua tempat. Kehidupan petani kemenyan yang tetap mempertahan kearifan lokal kemenyan didukung oleh organisasi-organisai masyarakat adat yang ikut perpartisipasi dalam menjaga kearifan lokal kemenyan. Mekanisme dan srategi yang petani kemenyan lakukan yaitu demonstrasi dan mencoba menghentikan pihak perusahaan saat beroperasi di wilayah hutan kemenyan.
\end{abstract}

Kata Kunci: Kemenyan, Kearifan lokal, Endemik, Nilai-nilai kultural

\section{PENDAHULUAN}

Sumber daya alam merupakan kekayaan alam yang berada di bumi dan dapat dimanfaatkan untuk memenuhi kebutuhan hidup manusia. Keberhasilan dalam mengelola sumber daya alam tersebut adalah salah satu faktor yang mempengaruhi kehidupan masyarakat dibidang sosial ekonomi. Ketersediaan sumber daya alam di bumi dimanfaatkan oleh para petani dan dikelola dengan baik sehingga mampu membentuk sendi-sendi kehidupan yang mapan.

Para petani memanfaatkan kekayaan alam dan berusaha untuk menjaga serta melestarikannya agar mampu memenuhi kebutuhan hidup. Kemenyan adalah salah satu kekayaan alam yang dimanfaatkan oleh masyarakat Desa Pandumaan Sipituhuta. Kemenyan ini dimanfaatkan dan dikelola dengan baik serta memiliki nilai jual. Sehingga keberhasilan dalam mengelola sumber daya alam ini mampu memenuhi kebutuhan hidup para petani.

Pohon kemenyan merupakan salah satu pohon yang perlu dilestarikan dan dibudidayakan karena pohon tersebut tidak selalu dapat ditanam dengan baik dalam setiap tempat atau daerah. Tumbuhan seperti ini biasanya disebut dengan tumbuhan endemik. Endemik atau endemis berarti eksklusif asli pada suatu tempat (biota). Suatu jenis tumbuhan dikatakan endemik apabila keberadaannya unik di suatu wilayah dan tidak ditemukan di wilayah lain secara alami. Pohon kemenyan juga akan punah dan mati berlahan-lahan tanpa pohon yang lain.

Pohon kemenyan dapat ditanam dan menghasilkan getah yang baik jika ada tanaman pelindung atau pohon alam lainnya. Sehingga pohon kemenyan ini biasanya tumbuh di hutan dan jauh dari tempat pemukiman. Pada umumnya orang batak menyebutnya 'tombak haminjon' yang artinya hutan kemenyan.

Hutan kemenyan atau "tombak haminjon" merupakan tanaman unggulan di Desa Pandumaan dan merupakan mata pencaharian utama masyarakat desa tersebut. Hal ini disebabkan popuasi pohon kemenyan yang cukup luas dan berkualitas baik khususnya di desa Pandumaan Sipituhuta.

Berdasarkan survey awal penelitian, pohon kemenyan dikenal oleh masyarakat pembuka Desa Pandumaan yaitu leluhur mereka. Leluhur mereka telah 
lama mengenal tanaman kemenyan yang dulu masih digunakan untuk ilmu-ilmu spiritual dan menurut sejarah tanaman kemenyan ini adalah seorang perawan yang pergi lari kehutan karena dipaksa menikah oleh orangtuanya.

Pohon kemenyan dikelola secara turun temurun dari satu generasi diwariskan ke generasi berikutnya hingga saat ini. Pewarisan atau pengalih tangan hak dilakukan secara hukum adat atau kebiasaan yang berlangsung secara terus menerus. Pengukuhan kepemilikan dan pemetaan kawasan hutan kemenyan biasanya ditentukan berdasarkan hukum adat. Tidak ada seorang warga yang berani menjual kawasan atau lahan yang mereka miliki pada pihak lain di luar komunitas masyarakat Pandumaan.

Namun, sebagian dari masyarakat adat Desa Pandumaan mudah tergoda dengan iming-iming pihak swasta. Masyarakat Pandumaan yang memiliki penghasilan yang cukup dari hasil panen kemenyan namun tergiur akan iming-iming dari pihak swasta yang ingin mendirikan kawasan industri di daerah tersebut.

Perusahaan industri berfungsi sebagai perusahaan pulp dan rayon menjadi produksi pulp (bubur kertas). Pihak perusahaan melakukan perluasan areal penanaman hutan tanaman insdustri. Demi kepentingan perusahaan, hutan kemenyan yang masuk dalam areal konsesi perusahaan ditebangi dan diganti dengan eucalyptus sebagai bahan baku industri pulp.

Namun, masyarakat desa Pandumaaan tetap mempertahankan hutan kemenyan. Keunggulan dan keunikan pohon kemenyan menjadi alasan petani kemenyan untuk tetap mempertahankan warisan budaya tersebut. Kearifan lokal ini harus tetap dijaga dan dipertahankan karena menjaga pohon kemenyan sama halnya dengan menghormati warisan nenek moyang. Berbagai tuntutan para petani kemenyan disampaikan, seperti pernyataan hutan adat bukanlah hutan negara. Upaya untuk memahami kehidupan petani kemenyan dalam mempertahankan kearifan lokal tersebut perlu dilakukan melalui proses penelitian selanjutnya.

Bedasarkan latar belakang yang telah dikemukakan diatas, membuat peneliti tertarik untuk meneliti lebih lanjut mengenai Kehidupan Petani Kemenyan dalam Menjaga Kearifan Lokal di Desa Pandumaan Kec. Pollung Kab. Humbang Hasundutan.

\section{Petani Kemenyan}

Petani adalah seseorang yang bergerak di bidang pertanian, utamanya dengan cara melakukan pengelolaan tanah dengan tujuan untuk menumbuhkan dan memelihara tanaman. Pengelolaan tanah dan pemeliharaan tanaman tersebut memperoleh hasil dan digunakan untuk tanaman kebutuhan hidup sendiri ataupun menjualnya kepada orang lain. Tanaman yang dibudidayakan oleh petani sangatlah beranekaragam misalnya padi, jagung, jahe, kopi, kemenyan dan lain sebagainya.

Kemenyan adalah sejenis getah yang dihasilkan oleh pohon kemenyan (Styrax spp) melalui proses penyadapan. Sebagai salah satu hasil hutan bukan kayu getah kemenyan dapat diolah dan dimanfaatkan untuk berbagai kegunaan. Sesuai Peraturan Menteri Kehutanan Nomor P.35/Menhut/2007 tentang Hasil Hutan Bukan Kayu, kemenyan ditetapkan sebagai salah satu hasil hutan bukan kayu (HHBK) nabati yang masuk dalam kelompok resin.

Petani kemenyan adalah seseorang yang bergerak dibidang pertanian dan mengelola kemenyan melalui proses penyadapan. Hasil getah kayu dapat diolah dan dimanfaatkan untuk berbagai kegunaan sehingga mampu meningkatkan kebutuhan dibidang ekonomi.

Kemenyan bagi petani dari sisi ekonomi merupakan sumber kehidupan yang mampu memenuhi kebutuhan hidup. Dalam Sosiologi ekonomi hubungan antara masyarakat yang melakukan interaksi sosial dengan ekonomi dapat didefenisikan dengan 2 cara. Pertama, sosiologi ekonomi didefenisikan sebagai sebuah kajian yang mempelajari hubungan antara masyarakat, yang di dalamnya terjadi interaksi sosial dengan ekonomi. Juga sebaliknya, bagaimana ekonomi mempengaruhi masyarakat. Kedua, sosiologi ekonomi didefenisikan sebagai pendekatan sosiologis yang diterapkan pada fenomena ekonomi (Damsar dan Indrayani, 2009:11). Sedangkan menurut Schumpeter sosiologi ekonomi berhubungan dengan konteks institusional dari ekonomi, sedangkan ekonomi berhubungan dengan ekonomi itu sendiri.

Selain bermanfaat dalam bidang ekonomi, pengelolaan kemenyan juga dapat bermanfaat dalam bidang sosial budaya. Petani kemenyan merawat nilai kultural yang ada pada pohon kemenyan agar tetap arif. Sehingga pohon kemenyan dikatakan sebagai warisan nenek moyang dan dijadikan sebagai kearifan lokal. Kemenyan yang termasuk sebagai tradisi titipan budaya lokal yang diwarisi secara turun-temurun kemudian dikelola secara tradisional.

Kemenyan (Stryrax $s \mathrm{p}$ ) yang termasuk famili Stryraccaceae dari Ordo Ebeneles diusahakan oleh rakyat Sumatera Utara di tujuh Kabupaten, terutama di Kabupaten Tapanuli Utara, Humbang Hasundutan, Pakpak Bharat, dan Toba Samosir. Tanaman ini juga dikembangkan di Dairi, Tapanuli Selatan, dan Tapanuli Tengah meski tidak terlalu banyak. Sedangkan penghasil kemenyan terbesar masih di Tapanuli Utara dan Humbang Hasundutan. 
Desa Pandumaan, Kabupaten Humbang Hasudutan satu desa yang masyarakatnya terkenal dengan petani kemenyan. Masyarakat penghasil kemenyan pada umumnya memiliki sumber mata pencaharian yang baik dan mampu meningkatkan nilainilai kultural. Kemenyan merupakan salah satu tanaman multifungsi. Kemenyan dibutuhkan manusia sebagai obat-obatan, parfum, digunakan untuk upacara adat spritual dan keagamaan.

\section{Kearifan Lokal}

Pengertian kearifan lokal (local wisdom) dalam kamus terdiri dari dua kata: kearifan (wisdom) dan lokal (local). Dalam disiplin antropologi dikenal istilah local genius.

Kearifan lokal atau kearifan tradisional yaitu semua bentuk keyakinan, pemahaman atau wawasan serta adat kebiasaan atau etika yang menuntun perilaku manusia dalam kehidupan di dalam komunitas ekologis (Keraf, 2002).

Dari ketiga defenisi ahli diatas dapat disimpulkan bahwa kearifan lokal merupakan pengetahuan lokal yang sudah demikian menyatu dengan sistem kepercayaan, norma dan budaya dan diekspresikan di dalam tradisi dan mitos yang dianut dalam waktu yang cukup lama. Pengetahuan lokal ternyata bisa menjadi salah satu solusi mengatasi dampak perubahan iklim disektor pertanian terutama dalam mengatasi krisis pangan ditingkat komunitas.

Sebuah penelitian terbaru dari International Institute for Environment and Development (IIED) mengungkapkan "kearifan lokal yang diajarkan turun temurun telah menuntun masyarakat tradisional yang terbelakang sekalipun mampu bertahan menghadapi perubahan iklim".

Budidaya tanaman kemenyan merupakan cara melestarikan kearifan lokal yang ada di Humbang Hasudutan. Tanaman lokal yang diturunkan secara turun temurun yang diwariskan oleh nenek moyang dan dipercayai sebagai titipan Ilahi untuk generasi berikutnya. Kearifan lokal ini perlu dibudidayakan dan dilestarikan karena hanya dapat berkembang dan tumbuh dengan baik dibeberapa tempat atau daerah. Untuk mendapatkan hasil panen kemenyan yang baik juga membutuhkan waktu beberapa tahun dan tenaga yang ekstra dan juga hasil panen kemenyan lebih menjanjikan.

\section{METODE PENELITIAN}

Penelitian ini menggunakan metode kualitatif yang bersifat deskriptif dan didukung dengan observasi yaitu peneliti melakukan pengamatan yang berusaha untuk mendeskripsikan data kualitatif sebanyak mungkin yang merupakan data utama untuk menjelaskan permasalahan yang nantinya akan dibahas. Lokasi penelitian dilakukan di Desa Brohol, Kecamatan Sei
Suka, Kabupaten Batubara untuk mendapatkan data dan juga informasi yang dibutuhkan. Peneliti memilih tempat ini sebagai lokasi penelitian karena di desa ini masih terdapat konsumen dan produsen jamu yang masih menjaga kualitas jamu sebagai obat tradisional.

Penelitian ini menggunakan dua jenis data yaitu data primer dan sekunder. Data primer adalah data yang diperoleh langsung oleh peneliti dari para responden melalui wawancara dan observasi pada produsen atau pembuat jamu (informan kunci) dan masyarakat yang mengkonsumsi jamu (informan biasa). Data sekunder merupakan data yang sudah tersedia, yang diperoleh dari berbagai buku ilmiah, jurnal, media massa, dan internet yang berhubungan dengan masalah penelitian yang akan diteliti.

Untuk memperoleh data dan informasi yang lengkap dan akurat, maka langkah-langkah yang diambil peneliti dalam mengumpulkan data adalah observasi dan wawancara. Penelitian ini menggunakan jenis observasi nonpartisipan atau observasi tanpa partisipasi. Dalam observasi tanpa partisipasi, peneliti hanya mengamati tanpa melibatkan diri dalam segala kegiatan yang berlangsung. Peneliti melakukan pengamatan hanya pada saat untuk memperoleh data mengenai masalah yang diteliti. Teknik observasi tanpa partisipasi ini digunakan oleh peneliti untuk melihat dan mengamati secara langsung keadaan di lapangan agar peneliti memperoleh gambaran lebih luas tentang permasalahan yang sedang diteliti. Hasil pengamatan ditulis dalam catatan lapangan yang bertujuan untuk memudahkan peneliti dalam menjelaskan data-data yang diperoleh dari hasil wawancara. Dalam mengumpulkan data, peneliti menggunakan alat bantu berupa alat tulis dan kamera untuk mengambil gambar yang berkaitan dengan penelitian.

Dalam penelitian ini peneliti menggunakan wawancara tidak terstruktur, dimana peneliti tidak menggunakan pedoman wawancara yang telah tersusun secara sistematis dan lengkap untuk mengumpulkan datanya. Pedoman wawancara yang digunakan hanya berupa garis-garis besar permasalahan yang akan ditanyakan. Dalam pelaksanaan penelitian, peneliti tetap menggunakan pedoman wawancara (interview guide) untuk mencegah terjadinya pergeseran maksud dan tujuan penelitian. Wawancara dilakukan untuk memperoleh keterangan mengenai masalah yang diteliti. Dalam hal ini yang menjadi interviewi adalah produsen dan konsumen jamu di Desa Brohol, Kecamatan Sei Suka, Kabupaten Batubara.

Untuk mendokumentasikan hasil penelitian yaitu menggunakan kamera. Teknik analisis data yang dilakukan pada penelitian ini adalah analisis data kualitatif yaitu mereduksi data berarti merangkum, memilih hal-hal yang pokok, memfokuskan pada hal-hal yang penting sehingga memberikan gambaran yang lebih jelas. Penyajian data bisa dilakukan dalam bentuk uraian singkat, bagan, hubungan antar kategori, flowchart dan sejenisnya. Kesimpulan dalam penelitian kualitatif merupakan temuan baru yang sebelumnya belum pernah ada. 


\section{HASIL DAN PEMBAHASAN}

\section{Fungsi dan Manfaat Kemenyan}

Kemenyan merupakan salah satu tumbuhan endemik. Tumbuhan Endemik merupakan tumbuhan asli yang hanya bisa ditemukan di sebuah wilayah geografis tertentu dan tidak ditemukan di wilayah lain. Wilayah disini dapat berupa pulau, negara, atau zona tertentu. Tumbuhan yang memiliki endemisitas tinggi rawan mengalami kepunahan kalau keberadaannya terdapat gangguan baik dari alam atau manusia.

Kemenyan adalah getah (eksudat) kering, yang dihasilkan dengan menoreh batang pohon kemenyan (Styrax spp., suku Styracaceae; terutama S. benzoin Dryand. dan $S$. paralelloneurus Perkins). Resin yang kering berupa keping-keping putih atau keputihan, yang terbenam dalam massa coklat bening keabuan atau kemerahan, keras namun rapuh, dan berbau harum enak. Kemenyan ini dalam perdagangan internasional dikenal sebagai kemenyan sumatra yang lainnya adalah kemenyan siam, yang lebih harum dan dihasilkan oleh $S$. tonkinensis dari Siam dan Tonkin.

Secara tradisional, kemenyan digunakan sebagai campuran dupa dalam kegiatan spiritual. Kegunaan Getah kemenyan, digunakan paranormal tapi untuk membuat dupa. Masyarakat yang menggunakannya mempercayai aroma wangi kemenyan bisa mengundang roh-roh halus yang dipanggil untuk mengobati orang yang sakit terkena ilmu hitam dan santet dan sebaliknya untuk yang jahat.

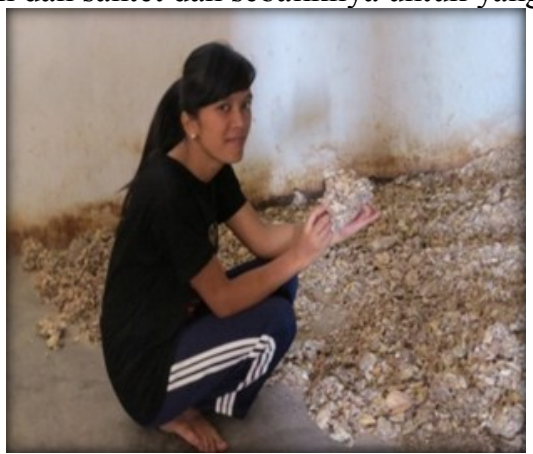

Gambar 1. Getah kemenyan atau " haminjon" yang sudah beku

\section{Sistem Pengelolaan dan Pemasaran Kemenyan}

Hutan kemenyan yang dimiliki oleh penduduk Desa Pandumaan ini terletak jauh dari perkampungan, sehingga para suamilah yang pada umumnya pergi ke "tombak" atau hutan untuk mengelola kemenyan tersebut. Kemenyan yang ada dihutan memiliki proses dan tahap-tahap untuk menjadi kemenyan yang baik dan memiliki harga yang cukup maksimal.

Setiap awal minggu atau hari Senin, suami sudah dibekali oleh istri dari rumah Atau tempat pemukiman. Segala peralatan dan perlengkapan disediakan dari rumah. Biasanya perlengkapan itu disediakan untuk jangka waktu yang cukup lama yaitu satu minggu. Mulai dari perlengkapan beberapa pakaian, makanan sehari-hari seperti beras, ikan, dan bahkan rokok untuk satu minggu. Semua itu sudah diperkirakan dalam jangka waktu satu minggu. Pada umumnya suami berangkat Senin dan kembali ke kampung pada hari Sabtu. Hal ini disebabkan letak "tombak" atau "hutan" yang cukup jauh dari pemukiman dan membuat mereka terpaksa menginap atau tinggal di hutan untuk sementara.

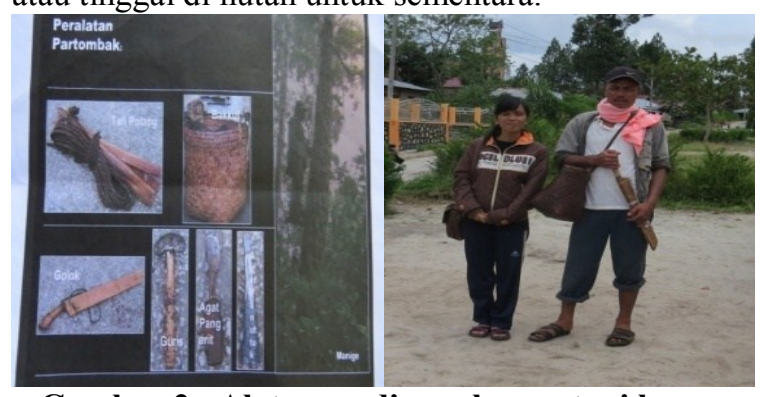

Gambar 2. Alat yang digunakan petani kemenyan

Berbagai peralatan tersebut digunakan dan masing-masing memiliki fungsi seperti, agak pagarit gunanya untuk membersihkan kulit pohon kemenyan yang telah kering, Guris gunanya untuk mengeluarkan semua kulit-kulit kemenyan yang tipis dan telah mengiring, Agat panuttuk gunanya untuk melukai kulit agar getah keluar dari tempat yang dilukai tersebut, Tali polang digunakan untuk memanjat pohon kemenyan, dan Bakkul digunakan sebagai tempat atau wadah getah kemenyan sebelum dituangkan ke tumpukannya.

Cara pengambilan getah kemenyan tersebut adalah sebagai berikut, pertama-tama pohon kemenyan yang sudah siap dipanen, dibersihkan kira-kira satu meter dengan menggunakan golok, kemudian dibuat 3 jalur sepanjang $40 \mathrm{~cm}$, lalu dalam jalur tersebut dibuatlah takikan-takikan sedikit sampai ke kayunya, jika dilihat dari samping menyerupai segitiga. Dari takikan tersebut keluarlah getah yang lambat laun mengeras dan harus segera diambil dan dikumpulkan. Kalau masa produksi pohon sedang bagus di pangkal batang tanaman diletakkan bambu-bambu sebagai penampung getah kemenyan. Hasil sadapan yang diperoleh kemudian dipilih untuk menentukan kualitasnya.

Dalam satu hari, satu orang hanya dapat mangguris (membersihkan) rata-rata 10 batang. Pada saat manige (menyedap), petani melantunkan syair:

$$
\begin{gathered}
\text { "parung simardagul-dagul } \\
\text { sahali mamarung } \\
\text { gok bakkul, } \\
\text { gok bahul-bahul", }
\end{gathered}
$$

Lantunan syair tersebut dipercayai semacam doa permohonan yang dinyanyikan dengan nada tertentu. Syair atau senandung petani kemenyan tersebut sekaligus meminta kepada sang penguasa agar mereka mendapat hasil yang memuaskan. Selanjutnya dilakukan manuktuk (mengetok) sekeliling kulit yang telah dibersihkan sebelumnya. Petani kemenyan lainnya yang mendengarkan syair ini wajib menjawab "ima tutu" (semoga). Sehingga apa yang mereka minta melalui latunan syair lagu tersebut seolah akan dijawab atau berhasil karena mereka yang meminta keberhasilan itu adalah orang-orang yang ada di hutan atau semua petani kemenyan. 
Setelah hari Senin-Sabtu para suami di hutan, mereka membawa hasil panennya ke kampung dan dijual kepada agen kemenyan yang ada dikampung. Selanjutnya, agen yang ada dikampung mengumpulkannya sampai dengan waktu yang cukup lama yaitu beberapa bulan. Setelah kemenyan yang dijual oleh petani kemenyan yang ada di hutan kepada agen yang di dikampung, maka kemenyan tersebut dijual kembali kepada agen yang ada di ibu kota kecamatan yaitu Dolok Sanggul.

Kemudian kemenyan yang sudah dijual di Dolok Sanggul akan diolah kembali dengan cara memilah-milah kemenyan. Biasanya kemenyan yang paling mahal yaitu kemenyan yang berwana putih asli yang biasa disebut dengan "mata kasar" mata kasar adalah getah kemenyan yang paling murni atau asli. Sedangkan kemenyan yang berwana kecoklat-coklatan yang disebut dengan "tahir" lebih murah dibadingkan dengan kemenyan yang berwana putih, karena tahir sudah merupakan kualitas kedua dari kemenyan yang murni.

Dalam penjualan getah kemenyan, hasil panen petani kemenyan dikelompokkan ke dalam dua kelas yaitu kualitas pertama yang dikenal dengan "mata kasar" dan kualitas kedua yang dikenal dengan istilah "tahir". Pada saat pelaksanaan penelitian ini harga getah kualitas kemenyan untuk kualitas pertama dihargai Rp 100.000 per kilogram sedangkan untuk kualitas kedua dihargai Rp 70.000 per kilogram. Secara umum petani melakukan pengolahan getah kemenyan terlebih dahulu sebelum dijual karena akan memperoleh harga yang lebih tinggi. Namun pada saat tertentu karena terdesak memenuhi kebutuhan keluarga, petani menjual langsung getah tanpa melakukan pengolahan.

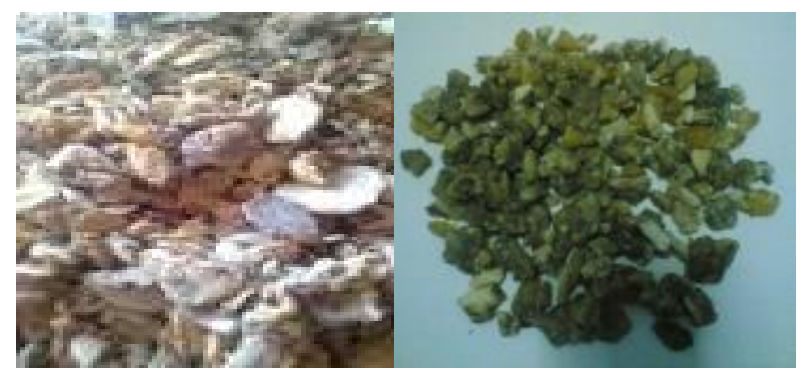

Gambar 3. Getah kualitas mata (kiri) dan tahir (kanan)

Dari sektor pertanian/perkebunan, haminjon merupakan komoditi unggulan daerah bagi Kabupaten Humbang Hasundutan, dengan jumlah produksi +60 ton/bulan. Sedangkan data yang diperoleh dari Dinas Pertanian Kabupaten Humbang Hasundutan menyatakan produksi tanaman kemenyan pada tahun 2004 sebesar 1.129,30 ton dan 4.559,28 ton pada tahun 2005.

Masyarakat Kabupaten Humbang Hasundutan umumnya hidup dari sektor pertanian/perkebunan. Dalam hal ini lebih dari 60 persen warga Humbang Hasundutan, Sumatera Utara, bekerja di sektor perkebunan kemenyan dengan nilai transaksi diperkirakan mencapai $\operatorname{Rp} 2,1$ Miliar tiap minggunya.

Hal ini disebabkan tanaman kemenyan dapat tumbuh dengan baik hanya di daerah Kabupaten
Humbang Hasundutan khususnya di kecamatan Pollung Desa Pandumaan. Untuk kecamatan Pollung, berdasarkan data yang diperoleh dari Dinas Pertanian Humbang Hasundutan menyatakan Produksi Tanaman kemenyan tahun 2005 sebesar 14, 64 ton.

Dari data di atas terlihat bahwa sumber penghasilan utama masyarakat di daerah ini adalah kemenyan. Data ini juga menunjukkan betapa kemenyan sangat dibutuhkan dan sangat berguna bagi banyak orang atau pihak. Berbagai manfaat dan fungsi kemenyan yang digunakan untuk kepentingan obat, bahan kosmetik, acara ritual adat dan keagamaan, dan sebagainya. Dapat dibayangkan apabila Tombak Haminjon punah, berapa banyak orang atau pihak yang terganggu dan dirugikan karena kesulitan dalam mencari kemenyan.

\section{Kemenyan Dalam Kearifan Lokal Sejarah atau Mitos Tentang Kemenyan}

Daerah penghasil kemenyan di Tanah Batak, Humbang Hasundutan, ada cerita rakyat yang terus diwariskan secara turun temurun. Dipercayai bahwa kemenyan berasal dari seorang putri cantik dari keluarga miskin. Dia nekat lari ke hutan karena dipaksa harus dinikahkan sebab orang tuanya terjerat utang kepada raja. Selama di hutan dia terus menangis memikirkan nasibnya dan juga keluarganya. Hingga kemudian dari tubuh si gadis tersebut pun perlahan-lahan tumbuh daun dan tetap mengeluarkan cairan dan akhirnya menyerupai pohon.

Oleh kepercayaan masyarakat di sana pun mengatakan bahwa dari cairan berupa getah yang keluar dari si gadis tersebutlah asal mula getah kemenyan. Dan kemudian orang tua si gadis tersebut pun dapat melunasi utangnya dari getah kemenyan. Bagi orang Batak getah kemenyan tersebut pun akhirnya mampu memberikan kesejahteraan. Karena banyak orang dapat merasakan manfaat dari kemenyan hingga akhirnya tergolong produk mahal karena digunakan oleh masyarakat di seluruh penjuru dunia.

Maka berdasarkan mitos tersebut, dipercayai kemenyan tidak akan menghasilkan getah jika lelaki bersikap buruk terhadap isterinya. Dalam hal ini, kaum perempuan juga dilarang ikut ke hutan, karena alasan tradisi tersebut. Kaum perempuan hanya berperan dalam pemasaran saja tetapi dalam pengelolaan di hutan kaum perempuan dilarang ikut. Hingga saat ini, pengelolahan kemenyan masih dilakukan para suami kecuali suaminya meninggal maka pekerjaan itu dilakukan oleh perempuan tetapi tetap didampingi oleh lelaki. Misalnya anak atau sanak saudara lelaki yang ikut mendampingi ke hutan.

Pantangan lain yang harus dipatuhi adalah memakai pakaian sederhana atau bisa dikatakan tidak bagus. Hal ini dimaksudkan untuk mengiba para penguasa pohon kemenyan supaya getah kemenyan dikeluarkan cukup banyak. Tradisi yang dilakukan para petani ini jauh sebelumnya sudah dilaksanakan nenek moyang pada zaman dahulu.

\section{Kemenyan sebagai Sumber Mata Pencaharian}

Pohon kemenyan merupakan sumber utama mata pencaharian penduduk desa Pandumaan. Seperti penjelasan sebelumnya hutan kemenyan itu bagi 
masyarakat setempat diibaratkan sebagai nafas kehidupan yang mampu membiayai kehidupan sehari-hari. Hal ini diakibatkan luas wilayah hutan kemenyan $40 \%$ dari keseluruhan luas wilayah desa tersebut. Sehingga penduduk desa Pandumaan memanfaatkan hutan kemenyan sebagai sumber mata pencaharian yang mampu memenuhi kebutuhan hidup.

Minat masyarakat Kecamatan Pollung, Kabupaten Humbang Hasundutan untuk menanam kemenyan semakin meningkat. Berdasarkan penelitian Panusunan (2005), di salah satu desa yang memanfaatkan hutan rakyat kemenyan, yaitu Desa Simasom Kecamatan Parlilitan Kabupaten Humbang Hasundutan, hutan rakyat kemenyan memberikan peranan penting, yaitu sebesar $78,59 \%$ dalam pendapatan rumah tangga.

Hasil pengelolaan dari pohon kemenyan berperan penting dalam pendapatan rumah tangga karena getah kemenyan multifungsi dan dibutuhkan masyarakat. Secara umum, harga yang didapat petani untuk kualitas 1 adalah Rp. 100.000/kg sedangkang kualitas 2 adalah Rp. $70.000 / \mathrm{kg}$. Produktivitas rata-rata getah kemenyan yakni $44,17 \mathrm{~kg} /$ ha untuk kualitas 1 dan $21,56 \mathrm{~kg} / \mathrm{ha}$ untuk kualitas 2. Biaya produksi sebesar Rp. $25.000 / \mathrm{kg}$.

Berdasarkan keterangan informan, dalam 1 batang pohon kemenyan rata-rata memiliki 20 takik (lubang) yang dibuat per tahun dan setelah diukur didapat rata-rata $0,235 \mathrm{ons} /$ lubang sehingga dapat menghasilkan rata-rata $0,47 \mathrm{~kg} / \mathrm{batang} /$ tahun. Jumlah batang rata-rata per hektarnya adalah 200 batang. Sehingga diperoleh jumlah produksi kemenyan sebesar $94 \mathrm{~kg} / \mathrm{ha} /$ tahun.

Berdasarkan hasil ini, masyarakat desa Pandumaan hanya mengandalkan kemenyan sebagai sumber mata pencaharian yang berperan dalam pendapatan rumah tangga. Maka petani kemenyan meminta izin kepada penguasa alam melalui upacara adat ritual agar getah kemenyan yang dikeluarkan pohon kemenyan banyak.

\section{Nilai Kultural Kemenyan}

Masyarakat yang berada di Desa Pandumaan Kecamatan Pollung Kabupaten Humbang Hasundutan, percaya bahwa kemenyan memiliki nilai kultural yang sudah membudaya dalam kehidupan masyarakat. Nilai kultural yang terkandung dalam kemenyan berawal dari kepercayaan petani kemenyan terhadap sejarah maupun cerita yang dianggap sebagai nasehat nenek moyang terhadap mereka.

Kemenyan yang sudah diwariskan nenek moyang terhadap petani kemenyan menjadi sebuah indentitas tersendiri bagi masyarakat Desa Pandumaan. Identitas yang mengandung nilai-nilai historis dan kultural yang sangat kaya. Petani kemenyan memiliki kulturnya sendiri dalam aktivitas yang mereka lakukan saat berangkat ke hutan atau "tombak haminjon." Petani kemenyan harus suci dalam kata maupun sikap.

Dalam proses pengelolaan pun tidak bisa sembarangan, dimulai dari "manige" (menyadap) hingga panen. Dengan hati yang tulus, sikap santun, sabar, membujuk pohon kemenyan ibarat merayu seorang gadis agar mengeluarkan getah yang banyak. Biasanya diikuti dengan senandung yang dinyanyikan ketika proses pekerjaan berlangsung.

Keberangkatan petani kemenyan ke tombak haminjon adalah sebuah pekerjaan yang sakral dan penuh dengan nilai-nilai kultural. Sebelum pohon kemenyan dikerjakan, terlebih dahulu mereka berdoa kepada sang penguasa alam atau di desa Pandumaan kerap kali disebut dengan "Oppung mula jadi na Bolon." Kegiatan ini semacam acara makan sesaji yang diiringi dengan doa. Selanjutnya, segala peralatan disiapkan, dibersihkan, dan diasah. Pohon kemenyan akan dikerjakan satu per satu. Kemudian dalam tidur di hutan akan diperoleh petunjuk atau arah apakah pekerjaan petani kemenyan dapat dilanjutkan atau tidak. Jika mimpi bagus, maka pohon kemenyan yang lainnya dapat dikerjakan.

Selain sebagai sumber mata pencaharian yang mampu memenuhi kebutuhan hidup mereka, bahkan mampu menyekolahkan anak-anak mereka ke jenjang pendidikan yang lebih tinggi. Pohon kemenyan juga anugerah Tuhan yang harus dijaga dan dibudayakan, melalui kelestariannya dan tradisi-tradisi yang masih berlaku hingga saat ini.

Pengelolaan Tombak Haminjon tersebut dikelola menurut kebiasaan secara hukum adat sehingga menjadi sebuah kearifan lokal. Kebiasaan atau hukum adat yang hidup, diyakini, diakui, dan ditaati secara turun temurun menyangkut:

1. Kepemilikan dan peralihan kepemilikan

2. Penentuan batas-batas kepemilikan, diantara mereka maupun dengan komunitas desa dan kecamatan lain

3. Pemungutan dan penjualan hasil hutan kemenyan

4. Perawatan (ada ritual) dan

5. Pengambilan kayu.

Hukum adat yang diyakini, diakui, dan ditaati sejak dahulu kala merupakan sebuah pembentukan karakter terhadap warga Desa Pandumaan agar tetap menjaga dan membudidayaakan kemenyan. Dalam budaya Batak Toba adatlah yang menjadi hukum. Tidak tertulis namun terlaksana. Apabila hukum adat disalahgunakan maka hukum alam yang disebut sebagai karma akan terjadi dan akan dikucilkan dari desa tersebut.

Bagi masyarakat Batak Toba hukum adat itu berbeda dengan hukum pemerintahan. Hukum adat Batak Toba tidak tertulis namun terlaksana. Hukum itu merupakan aturan-aturan dari nenek moyang pada zaman dahulu dan dilaksanakan oleh generasi berikutnya. Hukum adat pada Batak Toba diresmikan melalui sebuah upacara adat dan dilaksanakan secara tradisional. Kemudian untuk pelaksanaanya, masyarakat Batak Toba sudah terarah sejak dini. Apabila ada masyarakat yang melanggar pantangan tersebut maka akan mendapat sanksi sosial dari masyarakat sekitar atau dikucilkan dari desa tersebut.

\section{Peran Petani Kemenyan Dalam Menjaga Kearifan Lokal} Kerusakan Kearifan Lokal

Kerusakan kearifan lokal di Desa Pandumaan disebabkan kehadiran perusahaan raksasa yang merampas tanah ulayat atau hutan adat. Perampasan tanah atau 
hutan adat tombak haminjon (hutan kemenyan) dan pengerusakan dan penebangan pohon-pohon alam beserta kemenyan yang ada di desa tersebut mejadi awal mula kerusakan kearifan lokal.

Penebangan hutan kemenyan secara sembarangan membuat banyak orang atau pihak yang terganggu dan dirugikan karena lahan pertanian akan berkurang dan juga populasi pohon kemenyan sebagai kearifan lokal akan terganggu. Perusakan areal tombak haminjon dengan membuka jalan-jalan baru oleh kawasan industri sebagai jalan untuk masuk dan keluar dari areal hutan dengan tujuan pengangkutan kayu hasil penenbangan, akan mengakibatkan kerusakan kearifan lokal dan juga konflik.

Awal konflik tersebut diawali dari ketidakan persetujuan dari masyarakat Desa Pandumaan, terkait dengan pohon-pohon kemenyan yang ditebangi dan diganti menjadi tanaman eucalyptus atau kayu alam yang digunakan untuk kepentingan dan bahan baku oleh perusahaan. Tentu hal ini bukan hanya merusak kearifan lokal sebagai tumbuhan endemik tetapi juga menganggu kehidupan petani kemenyan. Pohon kemenyan akan mati berlahan-lahan akibat penebangan kayu alam lainnya yang dapat menyerap air.

\section{Dampak Kerusakan Kearifan Lokal}

Kerusakan kearifan lokal di Desa Pandumaan membuat berbagai permasalahan dan kericuhan terjadi di desa tersebut. Dimulai dari kerusakan sumber hidup atau mata pencaharian pokok, kehilangan produk unggulan dari daerah pemerintahan setempat, identitas Batak Toba sebagai masyarakat adat, dan juga adat Batak masyarakat adat Desa Pandumaan akan terganggu.

Dari segi sosial dan ekonomi kerusakan kearifan akan berdampak pada:

1. Kegiatan sehari-hari petani kemenyan ketika mencari nafkah menjadi terganggu dan akan berpengaruh terhadap perekonomian petani kemenyan.

2. Petani kemenyan akan kehilangan mata pencaharian utama dan pekerjaan sehingga meninggkatkan jumlah pengangguran

3. Petani kemenyan akan menjadi buruh di atas tanah ulayat mereka sendiri

4. Biaya untuk kebutuhan sehari-hari dan untuk keperluan anak-anak untuk sekolah juga akan terganggu karena sumber pendapatan akan hilang.

Sedangkan dari segi Sosial budaya sebagai masyarakat yang harus merawat nilai-nilai kultural yang terkandung dalam pengelolahan kemenyan adalah :

1. Warga Desa Pandumaan sebagai petani kemenyan akan kehilangan identitas, kearifan lokal, kebiasaan atau hukum adat yang mengatur pola hubungan kekerabatan diantara komunitas setiap warga desa

2. Hubungan kekerabatan antara petani kemenyan akan terganggu karena batas populasi kemenyan yang mereka miliki sudah berubah atau berkurang.

3. Bagi daerah Kabupaten Humbang Hasundutan akan kehilangan produk unggulan yaitu kemenyan yang sering digunakan sebagai bahan upacara adat dan agama.

\section{Mekanisme Mempertahankan dan Menjaga Kearifan Lokal}

Usaha-usaha yang dilakukan masyarakat Desa Pandumaan untuk tetap mempertahankan kemenyan adalah suatu perjuangan yang pantas ditiru dan didukung. Kebersamaan mereka agar tetap mempertahanan hidup melalui hutan kemenyan dikembalikan kepada masyarakat adat merupakan suatu perjuangan hidup dan mati petani kemenyan. Warga Desa Petani kemenyan merupakan masyarakat yang senasib sepenanggungan sehingga memperkokoh atau menguatkan kebersamaan mereka dalam mempertahankan kearifan lokal.

Perampasan Tombak Haminjon (hutan kemenyan) yang sudah dimiliki dan dikelola secara turun temurun hingga berpuluh generasi oleh masyarakat Pandumaan, kecamatan Pollung, kabupaten Humbang Hasundutan (Humbahas). Menimbulkan kemarahan pada petani kemenyan. Para petani kemenyan berusaha mempertahankan hidup mereka dengan cara merebut kembali tanah atau hutan adat yang menjadi hutan negara. Para petani kemenyan demo atau unjuk rasa di kantor-kantor pemerintahan setempat.

\section{PENUTUP}

Secara keseluruhan dari hasil penelitian ini, ada beberapa hal yang dapat dijadikan sebagai kesimpulan antara lain:

1. Pengelolahan tombak haminjon atau hutan kemenyan merupakan bagian dari budaya dan kearifan lokal masyarakat khususnya petani kemenyan yang diwariskan secara turun-temurun. Kepemilikan tanah ulayat dan hutan kemenyan diantara mereka maupun dengan masyarakat adat di luar perkampungan mereka, dilakukan berdasarkan kebiasaan atau hukum adat. Tidak seorang pun diantara mereka yang boleh menjual areal yang mereka miliki dan usahai kepada pihak lain di luar komunitas desa mereka. Hal ini dilakukan agar petani kemenyan mempertahankan dan tetap mengelola kemenyan secara tradisional. Proteksi atau perlindungan yang diberikan petani kemenyan melalui pengelolaan hutan secara tradisional dan kepemilikan hutan secara hukum adat merupakan alasan petani kemenyan untuk melindungi dan merawat nilai-nilai kultural hutan kemenyan atau tombak haminjon.

2. Pohon kemenyan merupakan nafas kehidupan bagi petani kemenyan. Petani kemenyan telah mengelola hutan kemenyan selama ratusan tahun. Petani kemenyan menjaga pohon kemenyan sebagai kearifan lokal yang mengandung nilai-nilai kultural. Mereka memanfaatkan getah kemenyan sebagai sumber penghasilan. Kemenyan bagi mereka adalah simbol kesejahteraan yang mampu memenuhi kebutuhan hidup mereka sehari-hari bahkan petani kemenyan mampu menyekolahkan anak-anak mereka ke jenjang perguruan tinggi. Namun, kehadiran perusahaan di areal hutan 
kemenyan menjadi awal dari kerusakan hutan kemenyan. Perusakan dan penebangan pohonpohon alam secara sembarangan membuat banyak pihak yang terganggu dan dirugikan. Lahan pertanian dan populasi hutan kemenyan akan berkurang maka pohon kemenyan sebagai kearifan lokal juga akan terganggu. Persetujuan atau keputusan secara sepihak dengan perberian izin berdirinya perusahaan industri di areal hutan kemenyan membuat pihak industri secara leluasa menebangi pohon kemenyan dan menggantinya dengan kayu alam. Pemberian izin kepada pihak perusahaan juga merupakan tindakan penghancuran identitas masyarakat adat Batak secara sistematis. Sebab berapa banyak tanahtanah adat yang dulunya dimiliki dan diusahai orang Batak secara adat, bebas, dan mandiri tetapi sekarang sudah menjadi areal kawasan industri. Hutan alam atau adat sudah beralih fungsi dan menjadi hamparan eucalyptus perusahan. Eucalyptus atau kayu alam ditanam untuk kepentingan dan bahan baku perusahaan.

3. Strategi yang dilakukan petani upaya mempertahankan hutan kemenyan adalah Pengaduan dan tuntutan warga ke berbagai instansi melalui surat maupun aksi demonstrasi belum juga mendapat tanggapan dan penyelesaian yang pasti, bahkan terkesan pihak pemkab Humbahas membersihkan diri dan mengatakan bahwa hal ini bukan wewenang mereka tetapi wewenang pusat. Dan sementara itu, upaya yang dilakukan petani kemenyan dalam mempertahankan kearifan lokal hingga saat ini adalah menyurati instansi terkait, meminta dukungan dan solidaritas kepada berbagai pihak (perantau, gereja dan jaringan). Dalam hal ini, sudah banyak surat dukungan terhadap perjuangan masyarakat dua desa yang ditujukan ke instansi terkait, melakukan aksi menjaga lahan dan tetap melakukan aktifitas bertani kemenyan, melakukan aksi-aksi demonstrasi ke berbagai instansi, baik di tingkat II, tingkat I, dan Pusat, membangun jaringan (aliansi) di tingkat regional dan nasional.

\section{DAFTAR PUSTAKA}

Bagong Suyanto dan J. Dwi Narwoko.2007 Sosiologi Teks Pengantar \& Terapan. Jakarta: Kencana Prenada Media Group

Bungin, B. 2007. Penelitian Kualitatif. Prenada Media Group: Jakarta

Damsar \& Indrayani. 2009. Pengantar Sosiologi Ekonomi. Prenada Media Group: Jakarta

George Ritzer, Douglas J. Goodman.2007.TEORI SOSIOLOGI MODERN. Yogyakarta. Predana Media Group
Koentjaraningrat, dkk. 2003. Kamus Istilah Antropologi. Jakarta : Progres

Keraf, A. S. 2002. Etika Lingkungan Penerbit Kompas. Jakarta

Moleong, Lexy J.2012. Metode Penelitian Kualitatif. Bandung: PT. Remaja Rosdakarya

2010. Metode Penelitian Kualitatif.

Bandung: PT. Remaja Rosdakarya

Nader, L \& Todd, H.F, The Disputing Process Law in Ten Societies,Columbia University Press, New York, 1978

Rahyono, F.X. 2009. Kearifan Budaya dalam Kata. Jakarta: Wedatama Widyasastra.

Ranjabar, Jacobus. 2013. Sistem Sosial Budaya Indonesia. Bandung: Alfabeta

Soekanto, Soerjono 2001. Sosiologi Suatu Pengantar.Jakarta:PT. Raja Grafindo Persada

Sugiono. 2008. Metode Penelitian Pendidikan (Pendekatan Kuantitatif, Kualitatif, $\quad R \& D$ )

Bandung: Alfabeta

Zeitlin M Irving. 1995 Memahami Kembali Sosiologi. Gajah Mada University Press

Simanjuntak, Boby Raya, dkk. Analisis Pemasaran Kemenyan (styrax spp) (Studi Kasus. Kec. Pollung. Kab. Humbang Hasundutan). Jurnal. Vol 1. No. 1. (2012): Medan: USU. Diakses. 15 Januari 2014

Sitompul, Manuari. 2011. Kajian Pengelolaan Hutan Kemenyan (Styrax Sp) di Kab. Humbahas, Prov Sumatera Utara) Tesis

Sitepu, Lonaria. 2012. Pola Adaptasi Sosial Ekonomi Masyarakat Desa Suka Meriah Pasca Bencana Alam Gunung Sinabung. Skripsi diterbitkan. Medan FISIP Universitas Sumatera Utara.(http://repository .usu.ac.idhandle1 2345678931455, diakses tanggal 29 Januari 2014 pukul 13.20 WIB ) 